\title{
PLASMA LIPIDS IN ESSENTIAL HYPERTENSION
}

\author{
By IRVINE H. PAGE, ESBEN KIRK, AND DONALD D. VAN SLYKE \\ (From the Hospital of the Rockefeller Institute for Medical Research, New York)
}

(Received for publication October 7, 1935)

Because of the frequent presence of cholesterol in the arterial lesions which develop during hypertension, the possibility was pointed out by Lemoine (1911) that hypercholesteremia might be a predisposing factor to atheromatosis. That it can be so in rabbits has been repeatedly demonstrated by administering cholesterol by mouth, with resultant production of hypercholesteremia and of atheromatous arterial lesions resembling those found in man (for literature see Wacker and Fahrig (1932)). The application of these results to other animals is made doubtful, however, by the fact that it is impossible to produce atheromatous lesions by feeding cholesterol to dogs or cats (Anitschkow (1925) ; Yuasa (1928)). Most investigators have failed to find hypertension in rabbits with arterial lesions produced by cholesterol (see review by Dominguez (1927)).

The first attempt to collect from human cases data bearing on the question appears to have been made by Lemoine (1911), who studied by a semiquantitative color test the cholesterol content of the serum in clinical hypertension, and found it abnormally high. Confirmatory results from cases of hypertension, only part of which were "essential," were reported by Pribram and Klein (1924) (47 cases, 76 per cent with high plasma cholesterol), Westphal (1924-5) (80 cases, 71 per cent high), and Gelman (1927) (37 cases, 68 per cent high. Wacker and Fahrig (1932) reported 12 cases of essential hypertension, with 18 control analyses of subjects with normal blood pressure. The normal cases averaged $152 \mathrm{mgm}$. of total cholesterol per $100 \mathrm{cc}$., with 180 as the maximum, while the cases of hypertension averaged 207 mgm., and all but 3 exceeded 180 .

On the other hand, Loewenstein (1928) reported 50 cases of hypertension, of which 4 were apparently nephritic and the rest essential; of the 50 he found only one with serum total cholesterol above $180 \mathrm{mgm}$. per $100 \mathrm{cc}$., which he considered the maximum normal value by the colorimetric method used. Weinstein and Weiss (1931) found high total cholesterol in only 5 of 37 cases of uncomplicated essential hypertension. Kirchgessner (1934) reported that most hypertensive subjects, in a series of 49 , showed high values for free cholesterol, although total cholesterol was usually normal. Bürger and Möbius (1934), in a paper appearing after our data were collected, found by the digitonin method entirely normal plasma concentrations of both free and total cholesterol in 20 cases of essential hypertension.

Alvarez and Neuschloss (1931), like Loewenstein, found normal total cholesterol values (colorimetric) in hypertension cases. They studied also, however, the ability of the serum to dissolve additional free cholesterol, and found that the sera of 21 out of 25 hypertension cases were supersaturated with cholesterol. Medvei (1932) attempted to confirm these results with regard to saturation, however, and was entirely unable to do so; he found the serum approximately saturated with cholesterol in both normal subjects and patients with hypertension. Only 2 of Alvarez and Neuschloss' 25 cases, and perhaps 8 of Medvei's 30, appear to be essential hypertension.

The available data show no agreement on the simple questions, (1) whether total cholesterol is high in the serum of patients with hypertension; and (2) whether the serum of such patients is supersaturated with free cholesterol. Only Kirchgessner's data, mostly colorimetric, bear on the question whether the ratio of free to esterified cholesterol is normal.

Data on plasma lipids other than cholesterol in hypertension are scant and contradictory. Wacker and Fahrig (1932) in the paper already quoted, found that phosphatides, neutral fats, free cholesterol, and esterified cholesterol all showed a similar tendency to a moderate increase in hypertension. Hoesch (1931) on the other hand found lipid phosphorus normal in essential hypertension (7 cases).

In view of the disagreement of results in the 
literature, we have determined, by the gasometric methods of Kirk, Page, and Van Slyke (1934) the plasma lipids of 16 patients in whom the diagnosis of essential hypertension appeared justified. Data from 2 patients with malignant hypertension also were obtained.

Methods and calculations are as described by the writers in the preceding paper.

Cases of essential hypertension studied. The cases reported in Table $I$ were classified as essential hypertension on the following grounds. They showed hypertension, which was idiopathic insofar as could be ascertained: in none of the cases had the hypertension been preceded by nephritis or other observed disease of probable significance. In all except the last 2 cases in the table the hemoglobin contents and urea clearances were still within or near the normal ranges. In Cases 15 and 16 shrinkage of the urea clearance had occurred, and decrease of hemoglobin. These were, however, late effects of a condition that had run a course typical of essential hypertension: the cases are therefore placed in this group. In all cases the plasma protein concentration was normal, a significant point in differentiating from chronic nephritis. In all cases except Number 16 urinary protein was absent or slight. The eyeground changes consisted of varying degrees of arteriolar constriction, perivasculitis, tortuosity of the vessels, and arteriovenous compression. Only 1 of the 16 patients was over 50 years of age.

The patients reported were all in fairly good physical condition, were satisfactorily consuming the usual ward diet, and were apparently free from complications such as might be expected to affect the blood lipids (for discussion of such conditions, physiological and pathological, see the chapter on lipoids in Peters and Van Slyke (1931)).

Results with essential hypertension. The data in Table I do not indicate the slightest tendency towards abnormality, in the total plasma lipid content, in the combined or free cholesterol, or in any other of the lipid fractions determined.

TABLE I

Essential hypertension



† All hemoglobin determinations by $\mathrm{O}_{2}$ capacity. Percentages calculated assuming normal for men to be 20.7 volumes per cent $\mathrm{O}_{2}$ capacity, for women 19.0 (Peters and Van Slyke, Vol. I, p. 544 (1931)). Plasma proteins were normal in all cases.

$\ddagger$ From Page, Kirk, Lewis, Thompson, and Van Slyke (1935), Table IV. 


\section{DISCUSSION}

Our results confirm those of Loewenstein (1928), Weinstein and Weiss (1931), Hoesch (1931), and Bürger and Möbius (1934), and are contrary to those of the authors, cited above, who observed increases of total or free cholesterol, or of plasma lipids, in essential hypertension. Nor do we find any abnormalities in the ratio of free to total cholesterol, or of any individual lipid to the total lipid content, when our results are compared with those obtained by Page, Kirk, Lewis, Thompson, and Van Slyke (1935) from normal men by the same methods used in the present work.

The causes which have led to numerous reports of cholesterolemia and lipemia in cases of hypertension are uncertain, but the following appear to be possible explanations :

1. The cases reported may in part not have been of the type which we define as essential hypertension. The clinical data given are too slight as a rule to outline the basis of the diagnoses. Loewenstein and Wacker and Fahrig have specified the cases in which they diagnosed the hypertension as essential, but some of the other authors have apparently not attempted a differentiation. In some cases the hypertension may have accompanied hemorrhagic nephritis, with more or less of the nephrotic syndrome, and the accompanying lipemia.

2. Some of the cases of essential hypertension reported may have been complicated by other nutritional, physiological, or pathological conditions conducive to lipemia. Our patients were apparently free from such complications, were receiving and consuming a normal diet, and the blood was drawn during the morning fast.

3. The assumed normal ranges of plasma lipid concentrations used as a basis of comparison may have been too low. With the exception of Kirchgessner (1934), none of the authors quoted above as finding high total or free cholesterol in hypertension has apparently controlled his results by comparison with analyses made by himself with the same methods on strictly normal plasma. Wacker and Fahrig do indeed report control analyses on 19 "Gesunde und Rekonvalescenten," who, however, were not all entirely healthy subjects. The normal ranges of Wacker and Fahrig for total lipids and total cholesterol are lower than those of Page, Kirk, Lewis, Thompson, and Van Slyke (1935). For total cholesterol the previous authors who have been quoted, except Kirchgessner (1934), have apparently assumed 160 or 180 mgm. per $100 \mathrm{cc}$. of plasma to be the upper limit of the normal range. Kirchgessner states, without giving data, that he finds $300 \mathrm{mgm}$. the upper limit by the colorimetric method, and 180 by the gravimetric digitonin procedure. The data of Page, Kirk, Lewis, Thompson, and Van Slyke (1935), by digitonin precipitation, indicate 232 mgm. as the mean normal value for total cholesterol, 307 mgm. as the limit exceeded by 1 normal out of 10, and 335 as the limit exceeded by 1 out of 20 .

4. The methods of lipid analysis used in the present study are different and, we believe, more accurate than those employed in most previous studies of hypertension. The cholesterol determinations, in the papers discussed above, have all been done colorimetrically except those of Bürger and Möbius and 1/3 of those of Kirchgessner. Mühlbock and Kaufmann (1931) found by the colorimetric method of Bloor from 176 to 82 per cent as much serum or blood cholesterol as by the digitonin method, and Kirchgessner found similar discrepancies, attributable to errors in the colorimetric method. For other lipids, apparently only Wacker and Fahrig followed Bloor's modern combustion technique or procedures of comparable accuracy.

That very high plasma cholesterol content in man, when it does occur, may possibly predispose to arteriosclerosis is indicated by observations on diabetic patients. Bloor, Buckner, and Gibbs (1932) found that the group of diabetics with the most advanced sclerosis showed the highest total and esterified plasma cholesterol contents, and that the proportion of cholesterol in esterified form was 10 to 15 per cent above the usual normal value. White (1934) found that diabetics with high plasma cholesterol contents were 15 times as likely to develop arteriosclerosis as diabetics with normal cholesterol.

These findings would support the possibility of hypercholesteremia as a causative factor in the arterial changes of essential hypertension, however, only if, in this disease, high plasma choles- 
terol could be shown to occur before or during the development of these changes. On the contrary, our results indicate that essential hypertension, if uncomplicated by other disorders tending to produce lipemia, is not accompanied by any disturbance of the plasma lipid picture.

\section{Malignant sclerosis}

Only two cases were available for these studies. The results are presented in Table II. The lipid values fall in or above the upper ranges found in normal subjects.
Anitschkow, N., Einige Ergebnisse der experimentellen Atheroskleroseforschung. Verhandl. d. deutsch. path. Gesellsch., 1925, 20, 149.

Bloor, W. R., Buckner, E., and Gibbs, C. B. F., Cholesterol ester percentage in diabetic plasma. Proc. Soc. Exper. Biol. and Med., 1932, 30, 63.

Bürger, M., and Möbius, W., Der Jod- und Cholesteringehalt des Blutes in seinen Beziehungen zur essentiellen Hypertonie. Klin. Wchnschr., 1934, 13, 1349.

Dominguez, R., Experimental atherosclerosis and blood pressure in the rabbit. J. Exper. Med., 1927, 46, 463.

Gelman, J., Hypertoniestudien. I. Hypertonie und Stoffwechsel. Ztschr. f. klin. Med., 1927, 106, 94.

Hoesch, K., Blutphosphatide und amine bei Nierenerkrankungen und ihre Beziehungen zum Hochdruck. Klin. Wchnschr., 1931, 10, 881.

TABLE II

Malignant hypertension

\begin{tabular}{|c|c|c|c|c|c|c|c|c|c|c|c|c|c|c|c|c|}
\hline \multicolumn{3}{|c|}{ Subject } & \multicolumn{6}{|c|}{ Clinical data } & \multicolumn{6}{|c|}{ Lipids per 100 ce. plasma } & \multirow{3}{*}{$\frac{\text { Total N }}{\substack{\text { atomic } \\
\text { ratio }}}$} & \multirow{3}{*}{$\frac{\text { Amino } N}{\begin{array}{c}\mathbf{P} \\
\text { atomic } \\
\text { ratio }\end{array}}$} \\
\hline \multirow{2}{*}{$\begin{array}{l}\text { Series } \\
\text { number }\end{array}$} & \multirow{2}{*}{$\begin{array}{l}\text { Hos- } \\
\text { pltal } \\
\text { num- } \\
\text { ber }\end{array}$} & \multirow{2}{*}{$\begin{array}{l}\text { Age } \\
\text { and } \\
\operatorname{sex}\end{array}$} & \multirow{2}{*}{ Date } & \multirow{2}{*}{$\underset{\text { pressure }}{\text { Blood }}$} & \multirow{2}{*}{$\begin{array}{l}\text { Urine } \\
\text { pro- } \\
\text { teins } \\
\text { for } 24 \\
\text { hours }\end{array}$} & \multirow{2}{*}{$\begin{array}{c}\text { Blood } \\
\text { ures } \\
\text { nitrogen } \\
\text { per } \\
100 \text { ce. }\end{array}$} & \multirow{2}{*}{$\begin{array}{c}\text { Ures } \\
\text { clear- } \\
\text { ance }\end{array}$} & \multirow{2}{*}{$\begin{array}{l}\text { Hemo- } \\
\text { globin }\end{array}$} & \multirow{2}{*}{$\begin{array}{l}\text { Total } \\
\text { lipid } \\
\text { C }\end{array}$} & \multirow{2}{*}{$\begin{array}{l}\text { Total } \\
\text { lipid } \\
\mathbf{P}\end{array}$} & \multirow{2}{*}{$\begin{array}{l}\text { Total } \\
\text { lipid } \\
N\end{array}$} & \multirow{2}{*}{$\underset{\mathbf{N}}{\operatorname{Lipid}}$} & \multicolumn{2}{|c|}{ Cholesterol } & & \\
\hline & & & & & & & & & & & & & Total & Free & & \\
\hline $\begin{array}{l}1 \\
1 \\
1 \dagger \\
2\end{array}$ & $\begin{array}{l}9050 \\
9050 \\
9050 \\
8784\end{array}$ & $\begin{array}{l}\text { years } \\
48 \mathrm{M} \\
48 \mathrm{M} \\
48 \mathrm{M} \\
31 \mathrm{~F}\end{array}$ & $\begin{array}{r}\text { February 14, } 1934 \\
\text { April 11, 1934 } \\
\text { April 16, 1934 } \\
\text { Ootober 1, } 1933\end{array}$ & $\begin{array}{c}m m . H_{\theta} \\
224 / 142 \\
260 / 170 \\
220 / 160\end{array}$ & $\begin{array}{c}\text { grams } \\
2.7 \\
9.3\end{array}$ & $\begin{array}{c}\text { mom. } \\
21 \\
16\end{array}$ & $\begin{array}{c}\text { per cent } \\
69 \\
31\end{array}$ & $\begin{array}{c}\text { per cent* } \\
96 \\
115\end{array}$ & $\begin{array}{c}\text { mom. } \\
750 \\
608 \\
831 \\
859\end{array}$ & $\begin{array}{r}\text { mom. } \\
13.0 \\
8.6 \\
7.9 \\
13.0\end{array}$ & $\begin{array}{c}\text { mom. } \\
49.9 \\
12.2 \\
13.6 \\
17.4\end{array}$ & $\begin{array}{r}\text { mom. } \\
11.5 \\
4.8 \\
4.1 \\
6.1\end{array}$ & $\begin{array}{c}\text { mgm. } \\
284 \\
221 \\
314 \\
371\end{array}$ & $\begin{array}{r}\text { mom. } \\
91 \\
98 \\
123 \\
97\end{array}$ & $\begin{array}{l}8.5 \\
3.1 \\
3.8 \\
3.0\end{array}$ & $\begin{array}{l}1.96 \\
1.23 \\
1.15 \\
1.05\end{array}$ \\
\hline
\end{tabular}

* 100 per cent $\mathrm{Hb}, 20.7$ volumes per cent $\mathrm{O}_{2}$ capacity for men, 19.0 for women.

$\dagger$ Blood taken after terminal apoplectic stroke.

\section{SUMMARY}

In 16 cases of uncomplicated essential hypertension the plasma lipids were determined by the methods of Kirk, Page, and Van Slyke (1934). In no case was the concentration of total lipids or of any of the lipid fractions outside the usual range of normal values, nor were the means and standard deviations of the group significantly different from those found in a group of normal subjects. Theories of the genesis of arterial changes in essential hypertension based on presumed hypercholesteremia, or on elevation of the cholesterol: phosphatide ratio, are, according to our results, without basis.

Only 2 cases of malignant sclerosis were available. They showed lipid concentrations in or above the upper ranges found in normal subjects.

\section{BIBLIOGRAPHY}

Alvarez, C., and Neuschloss, S. M., Untersuchungen ueber das Blutcholesterol bei arteriellem Hochdruck. Klin. Wchnschr., 1931, 1, 244.
Kirchgessner, G., Uber das verhalten des cholesterinstoffwechsels bei verschiedenen erkrankungen des gefässsystems. Klin. Wchnschr., 1934, 13, 976.

Kirk, E., Page, I. H., and Van Slyke, D. D., Gasometric microdetermination of lipids in plasma, blood cells, and tissues. J. Biol. Chem., 1934, 106, 203.

Lemoine, G., Du rôle de la cholestérine dans le développement de l'artério-sclérose et de l'athérome, Etude clinique et thérapeutique. Vigot Freres, Paris, 1911.

Loewenstein, W., Chemische Blutbefunde bei der essentiellen Hypertension und ihre Bewertung. Ztschr. f. klin. Med., 1928, 107, 52.

Medvei, C. V., Zur Frage des Blutcholesterins bei arteriellem Hochdruck. Klin. Wchnschr., 1932, 11, 414.

Mühlbock, O., and Kaufmann, C., Die gravimetrische Cholesterinbestimmung im Blut und Serum. Biochem. Ztschr., 1931, 233, 222.

Page, I. H., Kirk, E., Lewis, W. H., Thompson, W. R., and Van Slyke, D. D., Plasma lipids of normal men at different ages. J. .Biol. Chem., 1935, 111, 613.

Peters, J. P., and Van Slyke, D. D., Quantitative Clinical Chemistry, Volume I. Williams and Wilkins Co., Baltimore, 1931, p. 238.

Pribram, H., and Klein, O., Uber den Cholesteringehalt des Blutserums bei arteriosklerotischem Hochdruck. Med. Klin., 1924, 20, 572. 
Wacker, L., and Fahrig, C., Uber die mineralischen und lipoiden Bestandteile des Blutserums bei der essentiellen Hypertension im Vergleich zu den physiologischen Verhältnissen. Klin. Wchnschr., 1932, 11, 762.

Weinstein, A. A., and Weiss, Soma, The significance of the potassium-calcium ratio and of the inorganic phosphorus and cholesterol of the blood serum in arterial hypertension. Arch. Int. Med., 1931, 48, 478.

Westphal, K., Untersuchungen zur Frage der Entstehungsbedingungen des genuinen arteriellen Hoch- druckes. IV. Cholesterin als tonogene Substanz der genuinen Hypertension im Zusammenspiel mit anderen Entstehungsbedingungen. Ztschr. f. klin. Med., 1924-5, 101, 585.

White, P., Diabetes in children. Bull. New York Acad. Med., 1934, 10, 347.

Yuasa, D., Uber die experimentelle Cholesterinkrankheit bei Omnivoren. Beitr. z. path. Anat. u. allg. Path., $1928,80,570$. 